\title{
Fangliao Slide - a large slope failure in the upper Kaoping Slope off southwest Taiwan
}

\author{
Song-Chuen Chen ${ }^{1}$, Ching-Hui Tsai ${ }^{2}$, Shu-Kun Hsu ${ }^{2,3, *}$, Yi-Ching Yeh ${ }^{3}$, Char-Shine Liu ${ }^{4}$, \\ San-Hsiung Chung ${ }^{1}$, and Cheng-Yueh $\mathrm{Wei}^{1}$
}

\author{
${ }^{1}$ Central Geological Survey, Ministry of Economic Affairs, New Taipei City, Taiwan \\ ${ }^{2}$ Center for Environmental Studies, National Central University, Taoyuan City, Taiwan \\ ${ }^{3}$ Department of Earth Sciences, National Central University, Taoyuan City, Taiwan \\ ${ }^{4}$ Institute of Oceanography, National Taiwan University, Taipei City, Taiwan
}

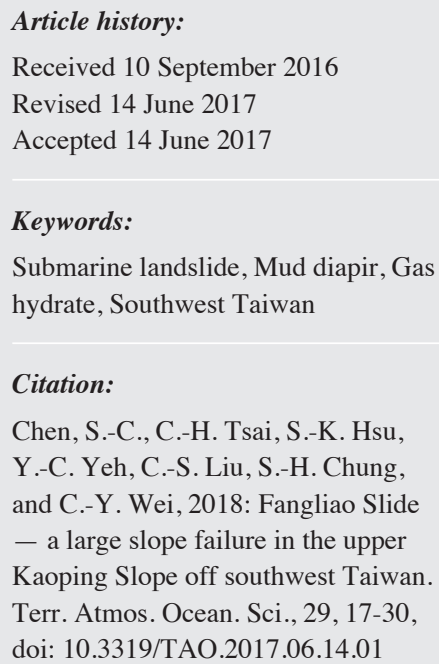

\begin{abstract}
Based on seismic reflection profiles and multi-beam bathymetric data, a large submarine landslide named Fangliao Slide is mapped for the first time off SW Taiwan. The Fangliao Slide occurred on the continental slope to the west of the Fangliao Canyon at water depths between 420 and $900 \mathrm{~m}$. The seafloor of the Fangliao Slide has a gentle slope angle $\left(\sim 1-2^{\circ}\right)$. The landslide covers an area of $\sim 15 \mathrm{~km}$ length and $\sim 10 \mathrm{~km}$ width and a volume of $\sim 26 \mathrm{~km}^{3}$. The headwall of the landslide has $\sim 30 \mathrm{~m}$ vertical offset at the southern flank of mud diapir MD7-1, and the sidewalls are bounded by fault $\mathrm{A}$ in the west and faults $\mathrm{C}$ and $\mathrm{D}$ in the east. The sliding area is composed of five bathymetric terraces, indicating that the slope failures have occurred several times. The Fangliao Slide can be divided into an upper domain and a lower domain, separated at the water depth of $\sim 600 \mathrm{~m}$ where the gas hydrate off SW Taiwan becomes dissociate. The initial slope failure of the Fangliao Slide was probably linked to mud diapirism of MD7-1 and the slope failure in the lower domain was probably augmented by the gas hydrate dissociation. The seafloor morphology in the lower domain is therefore more corrugated than in the upper domain.
\end{abstract}

\section{INTRODUCTION}

Submarine landslides occur frequently in both passive continental margins and active margins (Hampton et al. 1996; Wynn et al. 2000; Mienert et al. 2002; Korup et al. 2007; Twichell et al. 2009; Cukur et al. 2016). Submarine landslides have been studied extensively because they are important geohazards and can jeopardize the submarine infrastructures, such as offshore drilling platforms or submarine telecommunication cables, and can even trigger disastrous tsunamis (Bondevik et al. 2005; Hornbach et al. 2007, 2008; Hsu et al. 2008; Tappin et al. 2014; Li et al. 2015). Thick sedimentary deposits and inclined seafloor are commonly geological conditions favorable for submarine landslides (Hampton et al. 1996). The preconditioning factors of slope failure are associated with high environmental stresses (e.g., earthquakes, folds and submarine canyon fan systems)

\footnotetext{
* Corresponding author

E-mail:hsu@ncu.edu.tw
}

(Hampton et al. 1996) and overpressure in sedimentary layers due to rapid sedimentation and gas generation (Micallef et al. 2009; Urlaub et al. 2015; Cukur et al. 2016). Thus, gas hydrate dissociation could play an important role on generating slope failures (McIver 1982; Mienert et al. 2002; Horozal et al. 2017), as was hypothesized in the case of the Storegga Slide off Norway (Bunz et al. 2003; Berndt et al. 2005; Mienert et al. 2005; Brown et al. 2006; Micallef et al. 2009), the Cape Fear Slide off SE U. S. (Popenoe et al. 1993; Schmuck and Paull 1993), the Blake Ridge Collapse off SE U. S. (Booth et al. 1994; Dillon et al. 1998), the Humboldt Slide off California U. S. (Gardner et al. 1999; Yun et al. 1999), and the Gulf of Cadiz slides off SW Spain (Baraza et al. 1999). In the Storegga Slide, the area of gas hydrate dissociation is near the headwall of the slide and numerous fluid escape features were observed in the vicinity of the northern sidewall. It suggests that the Storegga Slide is closely related to gas hydrate dissociation (Berndt et al. 2005; Mienert et al. 
2005). However, the morphology of Storegga Slide shows a retrogressive slide mechanism (Kvalstad et al. 2005). Kvalstad et al. (2005) pointed out the initial triggering of the Storegga Slide was caused by the high excess pore pressure due to rapid sedimentation and earthquakes; the retrogressive upslope spreading of the slide was associated with the strain softening of marine clay. In the Gulf of Cadiz slides off SW Spain, gassy sediments and pockmarks covering more than $240 \mathrm{~km}^{2}$ were observed and frequent earthquake activities have been recorded. The triggering of the Gulf of Cadiz slides was due to the presence of steep slope $\left(7^{\circ}\right)$ in the upper slope, earthquakes and the presence of gas within sediments (Baraza et al. 1999). Leynaud et al. (2017) indicated the escarpment of $40 \mathrm{~m}$ high of the Gulf of Cadiz Slides was triggered by high-amplitude earthquakes or by accumulated displacement along a tectonic discontinuity. Overall, a slope failure is generally not triggered by only one factor but by a combination of several factors.

The seafloor slope is a crucial factor for submarine landslides (Hampton et al. 1996). A steep slope facilitates sediments to move downslope. However, submarine landslides may occur at a low slope angle (even less than $1^{\circ}$ ) (Kvalstad et al. 2005; Urlaub et al. 2015), especially when a landslide area is affected by gas hydrate dissociation and earthquakes. For example, the Storegga Slide has an average slope of less than $0.6^{\circ}$ and most of the area the slopes are less than $0.4^{\circ}$ (Kvalstad et al. 2005). In the Gulf of Cadiz slides the slope angles range from $0.5-1.5^{\circ}$ (Baraza et al. 1999).

The active continental margin off SW Taiwan is characterized by accretionary wedges, numerous submarine canyons across the continental slope (Liu et al. 1997, 2004), a few kilometers thick sedimentary deposits (Lin et al. 2009; Hsu et al. 2013a), numerous active mud diapirs and mud volcanoes, and gas seeps (Sun and Liu 1993; Liu et al. 1997; Chiu et al. 2006; Chen et al. 2010, 2014; Hsu et al. 2013b, 2018). A disastrous tsunami hitting the coastal area of southwest Taiwan in 1781 was reported (Chen 1830; Hsu 1983). The origin of the 1781 tsunami was considered to be a submarine landslide in the offshore area of southwest Taiwan ( $\mathrm{Li}$ et al. 2015). In 2006, several submarine landslides triggered by the Pingtung earthquake have induced turbidity currents off southwest Taiwan and destroyed several submarine telecommunication cables off SW Taiwan (Hsu et al. 2008). Likewise, small-scale submarine landslides were identified on the basis of bathymetric and geophysical data in the offshore area of southwest Taiwan (Liu et al. 2004; Hsu et al. 2008; Wu 2008; Chen et al. 2012; Yeh et al. 2015). However, due to a lack of detailed and highresolution marine geophysical data, a holistic understanding of the slope failure mechanism of the submarine landslides off SW Taiwan is still poor.

In this paper, we use new multi-beam bathymetry and high-resolution multi-channel seismic reflection (MCS) data to reveal a large-scale submarine landslide in the Ka- oping slope area and to discuss the possible mechanisms of the slope failures.

\section{GEOLOGICAL BACKGROUND}

The continental margin off SW Taiwan is situated in the area where the plate convergence between the Eurasian Plate and the Philippine Sea Plate changes from a subduction to an incipient collision and uplift of the Taiwan mountain belt (Ho 1986; Teng 1990; Reed et al. 1992; Liu et al. 1997, 2004; Ku and Hsu 2009) (Fig. 1). The deformation front (DF) is the northward continuation of the Manila Trench and separates the fold-and-thrust structures of the active accretionary wedge to the east from the horst-and-graben structures of the passive South China Sea (SCS) continental margin to the west (Fig. 1). The accretionary wedge off SW Taiwan can be further divided into the upper and lower slope domains, separated by a major thrust (MT) (Fig. 1) (Reed et al. 1992; Liu et al. 1997, 2006; Lin et al. 2009). The lower slope domain is characterized by a series of anticlinal ridges due to active thrusting and folding, and shows ridges and sedimentary basins topography. In contrast, the upper slope domain shows relatively smooth seafloor but is characterized by the steeply dipping beds and chaotic seismic structures (Liu et al. 2006; Lin et al. 2009). Thus, the tectonics of the lower slope domain is more active, though gas venting, mud volcanoes and diapiric structures exist in the upper slope domain (Sun and Liu 1993; Chiu et al. 2006; Chen et al. 2010, 2014; Hsu et al. 2013a, b).

The Kaoping Canyon (KC) and Fangliao Canyon (FC) are two major submarine canyons in the upper slope domain off SW Taiwan (Fig. 1). The Fangliao Canyon cuts the shelf edge and its channel is constrained by mud diapirs (Fig. 1) (Hsu et al. 2013a; Chen et al. 2014; Doo et al. 2015). Connecting to the Kaoping River in SW Taiwan (Fig. 1), the Kaoping submarine canyon is a main sediment dispersal system; lots of sediments have been transported to the offshore area of SW Taiwan (Huh et al. 2009; Yu et al. 2009). Based on MCS (multi-channel seismic reflection) profiles, there is a wide distribution of BSR (Bottom Simulating Reflector due to the reverse acoustic impedance) in the offshore area of SW Taiwan, suggesting enormous gas hydrate deposits may exist beneath the seabed off SW Taiwan (Fig. 1) (Liu et al. 2006; Chen et al. 2014).

\section{DATASETS AND METHODS}

Multi-beam bathymetric data were collected onboard R/V OR2 in 2010 by using the Atlas MD50 echo sounder operated at a frequency of $50 \mathrm{kHz}$. The Kongsberg EM710 and EM302 multi-beam echo sounders onboard M/V POLARIS, operated at frequencies of $76-100 \mathrm{kHz}$ and $26-34 \mathrm{kHz}$, were also used for the surveys in 2011. All the data were processed and compiled with the softwares CARAIBES and 
GMT, respectively. The grid resolution of multi-beam bathymetric data is $20 \mathrm{~m}$.

In this study, we use ten MCS profiles with a total length of $\sim 200 \mathrm{~km}$ for the structural interpretation (Fig. 2). The MCS profiles were collected with a high-resolution multi-channel seismic system in 2009, 2012, and 2013. Among all the profiles, MCS1009, MCS1030, and MCS21616 have a total length of $\sim 175 \mathrm{~km}$ and were collected by using 48,24 , and 12 channels with streamer lengths of 600 , 150 , and $75 \mathrm{~m}$, respectively. The MGL0908 profile used in this study has a length of $\sim 25 \mathrm{~km}$ and was collected by using 468 channels with a streamer length of $6000 \mathrm{~m}$ onboard R/V Marcus G. Langseth. All the MCS profiles were processed with a PROMAX interactive seismic processing software. Data processing included trace editing, geometry setup, band-pass filtering, amplitude compensation, predictive de- convolution, spiking noise removal, velocity analysis, normal move-out correction (NMO), stacking, water velocity F-K time migration and water column mute. Seismic data acquisition specifications at different cruises are shown in Table 1 . Here we only display the seismic profiles shown in Fig. 3.

\section{RESULTS}

Based on the MCS profiles and multi-beam bathymetric data, we have identified a large submarine landslide named "Fangliao Slide" together with five main normal faults A to E, surrounding the sliding area (Figs. 3 and 4). So far, the Fangliao Slide is the largest submarine landslide ever found off SW Taiwan. The Fanglaio Slide is bounded by the Fangliao Canyon in the west and is distributed at water

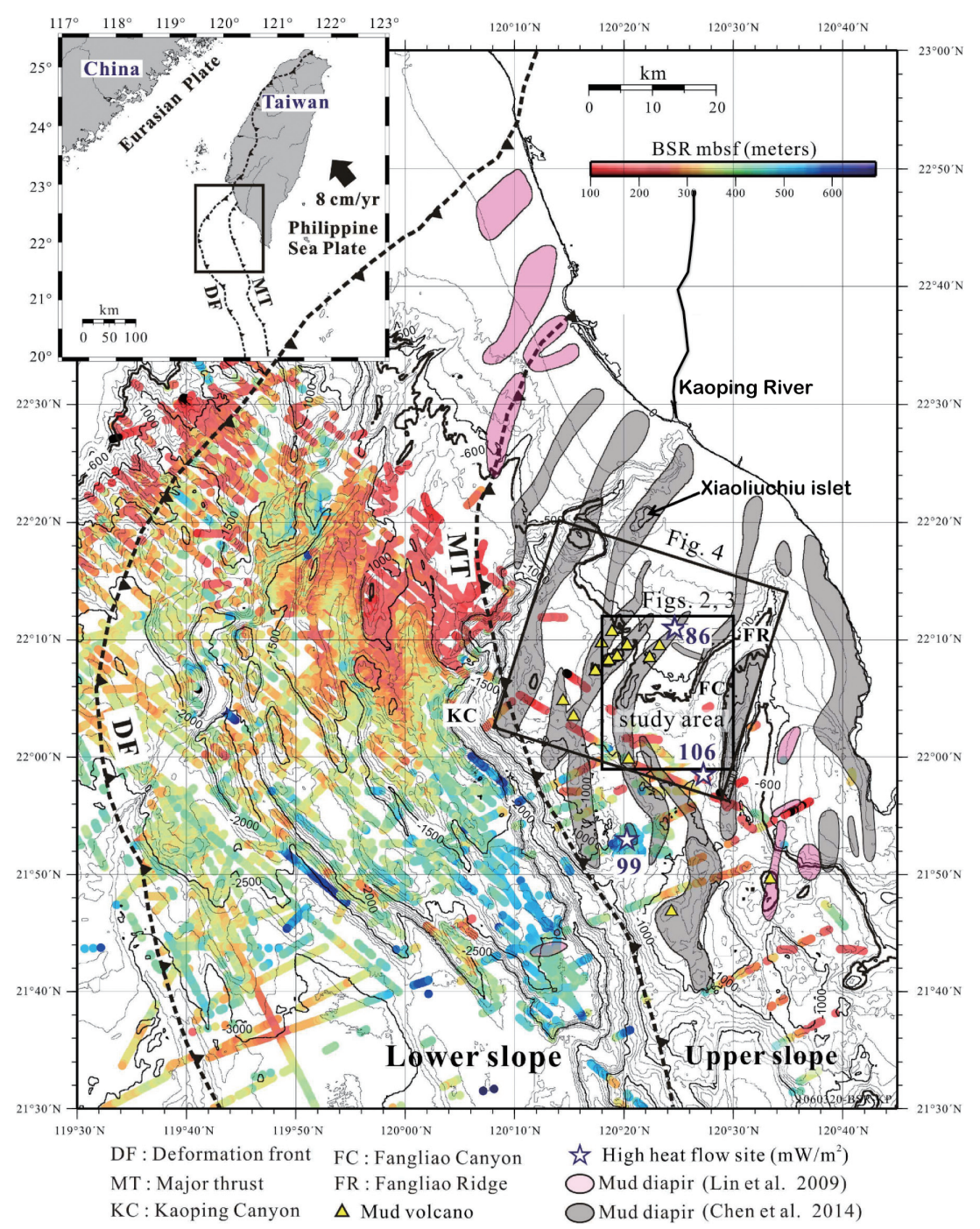

Fig. 1. Tectonic feature, bathymetry and related structures off SW Taiwan. Upper panel shows the regional topography and tectonic features. The deformation front (DF) separates the passive continental margin in the west and active accretionary wedge in the east. The major thrust (MT) separates the lower slope and upper slope of the accretionary wedge. The solid boxes indicate our study area. The distribution of the bottom simulating reflector (BSR) of Liu et al. (2006) is shown by the color scale. MBSF: meters below seafloor. 


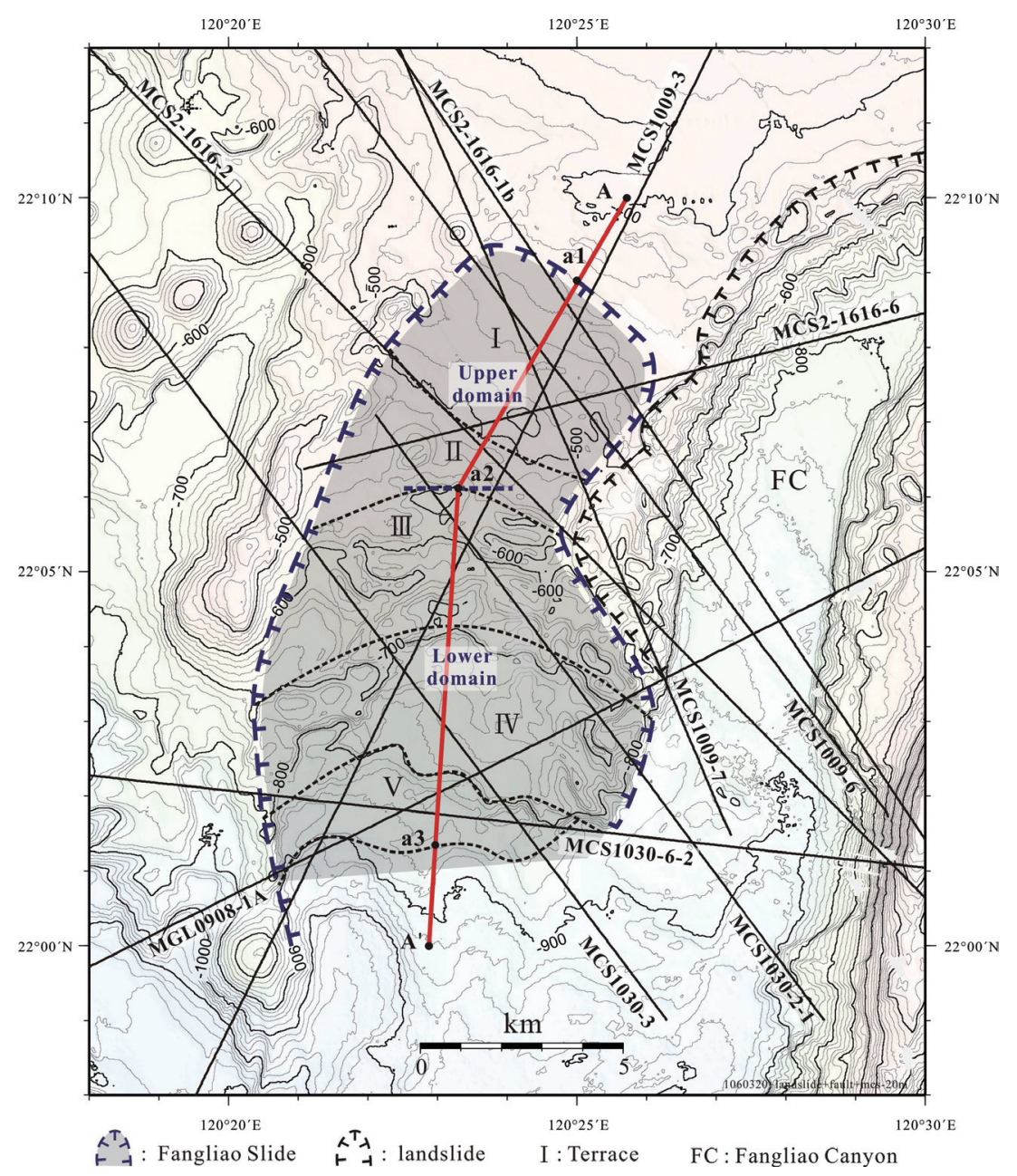

Fig. 2. Distribution of the seismic reflection profiles used in this study. Black lines are seismic profiles. The red line is the track of the bathymetric profile shown in Fig. 5.

Table 1. The seismic data acquisition specifications of the different seismic survey systems used in this study.

\begin{tabular}{c|cccc}
\hline MCS cruise & MGL0908 & MCS1009 & MCS1030 & MCS2-1616 \\
\hline Acquisition vessel & R/V Marcus G. Langseth & R/V OR1 & R/V OR1 & R/V OR2 \\
Source & 40 air guns array & 2 air guns & 1 GI-gun & 1 GI-gun \\
Source volumes (cu. in.) & 6000 & 550 & 420 & 90 \\
Shot interval (m) & 50 & 25 & 25 & 25 \\
Streamer length (m) & 6000 & 600 & 150 & 75 \\
No. channels & 468 & 48 & 24 & 12 \\
Channel interval (m) & 12.5 & 12.5 & 6.25 & 6.25 \\
Main frequency (Hz) & $40(4-128)$ & $100(8-200)$ & $125(16-400)$ & $125(16-400)$ \\
\hline
\end{tabular}



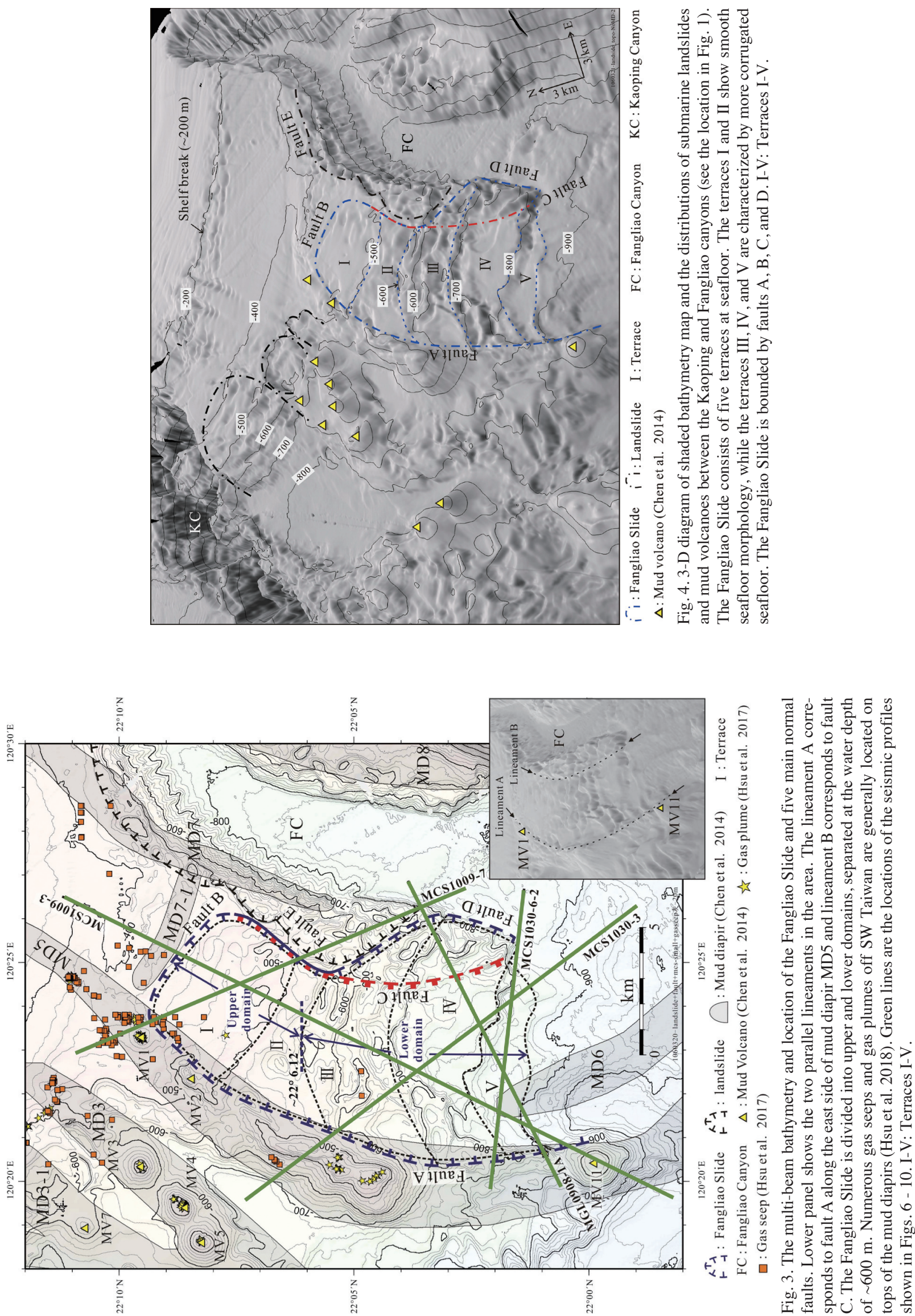
depths from 420 - $900 \mathrm{~m}$ (Figs. 3 and 4). With the exception of fault $\mathrm{E}$ that is related to the slumping along the western flank of the Fangliao Canyon, that faults (A to D) act as the boundaries of the Fangliao Slide.

\subsection{Fangliao Slide}

The Fangliao Slide generally shows a listric bottom with a sliding trend toward south. The headwall of the slide has about $30 \mathrm{~m}$ vertical offset and is located at the southern flank of mud diapir MD7-1 (Fig. 3). The sidewalls coincide with fault $\mathrm{A}$ in the west and faults $\mathrm{C}$ and $\mathrm{D}$ in the east, respectively (Fig. 4). The sliding has created five seafloor terraces (I - V) (Figs. 3 - 5). The boundaries between of the terraces are roughly along the bathymetric contours of 500, 600, 670, and $800 \mathrm{~m}$, respectively (Fig. 4). Based on the seafloor roughness, the Fangliao Slide can be divided into an upper domain and a lower domain, separated by the water depth of $\sim 600 \mathrm{~m}$ (Figs. 3 - 5).

The upper domain contains terraces I and II and has a relatively smooth bathymetry with a gentle slope of $\sim 1^{\circ}$, a length of $\sim 6 \mathrm{~km}$ and a width of $\sim 6 \mathrm{~km}$ (Figs. 3 and 5). Based on MCS profile MCS1009-7, the vertical transect of the upper domain is characterized by a wedge shape, bounded by fault $\mathrm{A}$ in the west and fault $\mathrm{C}$ in the east (Figs. 3 and 6). The upper domain covers an area of $\sim 37 \mathrm{~km}^{2}$ and comprises a slide volume of $\sim 7 \mathrm{~km}^{3}$. The lower domain consists of terraces III, IV, and V and has a corrugated seafloor with a steeper slope of $\sim 2^{\circ}$, a length of $\sim 9 \mathrm{~km}$ and a width of 6.3 $10 \mathrm{~km}$ (Figs. 3 and 5). The results indicate that the creeping of slope failure in the lower domain is more active than the upper domain. The lower domain covers an area of $\sim 79 \mathrm{~km}^{2}$ and a slide volume of $\sim 19 \mathrm{~km}^{3}$. The difference between the upper and lower domains suggests that the Fangliao Slide had several events of sliding. In total, the sliding area is estimated to be $\sim 15 \mathrm{~km}$ long and $6-10 \mathrm{~km}$ wide (area of $\sim 116 \mathrm{~km}^{2}$ ) and the slide volume is about $26 \mathrm{~km}^{3}$.

\subsection{Boundary Faults}

As mentioned previously, five main normal faults (faults A, B, C, D, and E) are identified around the Fangliao Slide. Faults A to D bound the Fangliao Slide (Figs. 3, 4, 6 - 10). Fault A has a length of $\sim 19 \mathrm{~km}$ and is located along the east side of mud diapir MD5 (Figs. 3, 6-10). The occurrence of fault A was probably due to the MD5 diapirism. The $\sim 5.3 \mathrm{~km}$ long fault B corresponds to the headwall of the slide and is located at the southern flank of mud diapir MD7-1 (Figs. 3, 4, 10). The arc-shaped fault $\mathrm{C}$ has a total length of $\sim 11.5 \mathrm{~km}$. North of $\sim 22^{\circ} 6.12^{\prime} \mathrm{N}$, fault $\mathrm{C}$ coincides with the eastern boundary of the Fangliao Slide (Figs. 3, 4, and 6), while south of $\sim 22^{\circ} 6.12^{\prime} \mathrm{N}$ fault $\mathrm{C}$ is located inside of the sliding area (Figs. 3, 4, and 8). Fault D has a length of $\sim 8 \mathrm{~km}$ and is located at the western flank of Fangliao Canyon. Fault $\mathrm{D}$ is distributed to the south of $22^{\circ} 6.12^{\prime} \mathrm{N}$ and coincides with the eastern boundary of the lower domain of the slide (Figs. 3, 4, and 8). Fault E is outside the Fangliao Slide area and is associated with the lateral slumping of the western flank of the Fangliao Canyon (Figs. 3, 6, and 8).

Fault $\mathrm{A}$ and fault $\mathrm{C}$ have obviously morphological features (Fig. 4). The bathymetric lineaments are continuous at seafloor even in the rapid sedimentation rates of $0.7-4.5 \mathrm{~mm} \mathrm{yr}^{-1}$ (Lin et al. 2014) environment off southwest Taiwan. It indicates that the faults are active in an active mud diapirism area. Based on seismic profile MCS1009-7, active fault $\mathrm{C}$ is dipping westward and a clear scarp exists at seafloor (Fig. 6).

\section{DISCUSSION}

\subsection{Slope Failure Due To Mud Diapirism}

As mentioned previously, the headwall of the Fangliao Slide is located at the southern flank of mud diapir MD7-1 where the sedimentary strata dip downslope (Figs. 3 and 10). The headwall marked by fault B connects the basal sliding surface of the Fangliao Slide (Fig. 10). Based on the seismic structures, fault B was probably induced by the uplift of mud diapir MD7-1 (Fig. 10). The western boundary of the Fangliao Slide is along fault $\mathrm{A}$ and is also along the eastern flank of MD5 (Figs. 3,6 - 9). We suggest that fault A was induced by the mud diapirism of MD5. The uplift of MD5 caused the onlap stratigraphy and normal fault A along the eastern flank of the diapir. Normal faults associated with diapiric structures are quite common (Tvedt et al. 2016). Therefore, the sliding of the Fangliao Slide is likely to have been initiated by the activity of mud diapirism.

\subsection{Slope Failure Due To Dissociation of Gas Hydrate}

The dissociation of gas hydrate releases 150 - 180 times its volume in natural gas and 0.8 times its volume in water (Kvenvolden 1998), which leads to high excess pore pressure (overpressure) in sedimentary layer and can lower sediment shear strength. The dissociated gases thus can induce slope failures in continental slopes (McIver 1982). In addition, the landward migration of the free gas beneath the base of gas hydrate stability zone (BGHS) may reduce the stability of the overlying sediment mass due to excess pore pressure ( $\mathrm{Li}$ et al. 2016). Thus, either the dissociation of gas hydrate or the upward migration of the free gas beneath the BGHS can weaken sediment strength and increase slope instability.

In the west of the Fangliao Slide lower domain, BSRs are distributed beneath the western side of mud diapiric ridge MD5 (Figs. 8 and 10). Several high amplitude reflections beneath the slope failure plane in the lower domain are observed (Fig. 9). The high amplitude reflections display an acoustically reversed polarity relative to the seafloor, 


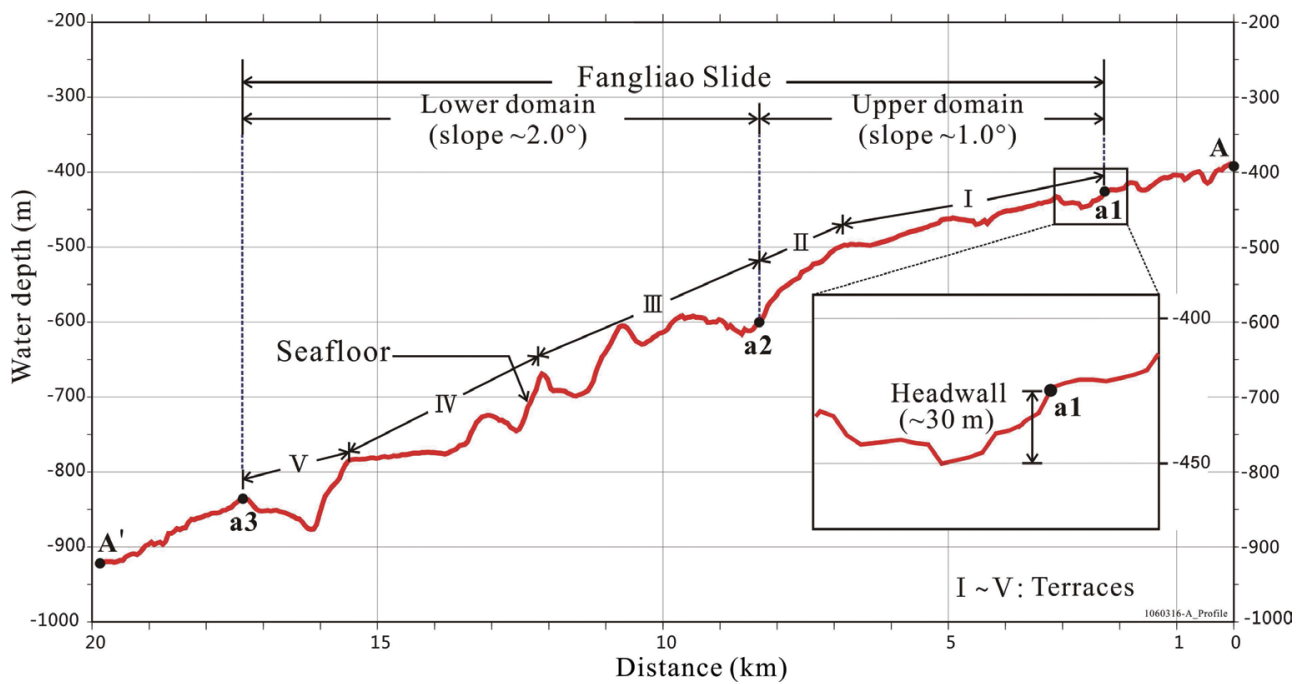

Fig. 5. A bathymetric profile along the sliding direction of the Fangliao Slide. The headwall has $\sim 30 \mathrm{~m}$ vertical offset. The upper domain contains terraces I and II with a gentle slope of $\sim 1^{\circ}$. The lower domain contains terraces III to V with a slightly steeper slope of $\sim 2^{\circ}$. The profile location is shown in Fig. 2.
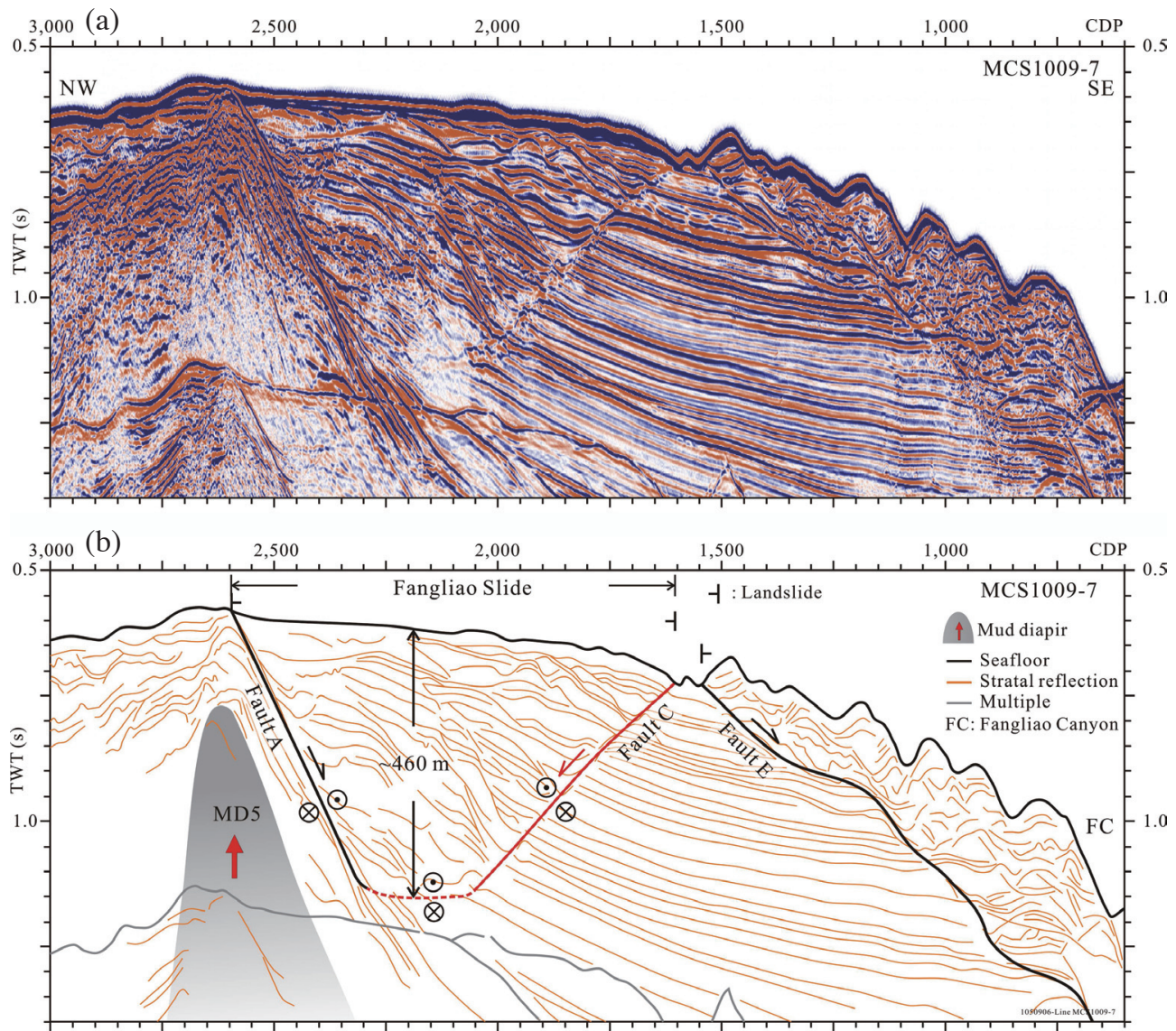

Fig. 6. (a) MCS profile MCS1009-7 and (b) the seismic interpretation. The upper portion of the Fangliao Slide shows a wedged shape; the wedge is bounded by fault $\mathrm{A}$ in the west and fault $\mathrm{C}$ in the east. See the profile location in Fig. 3. 

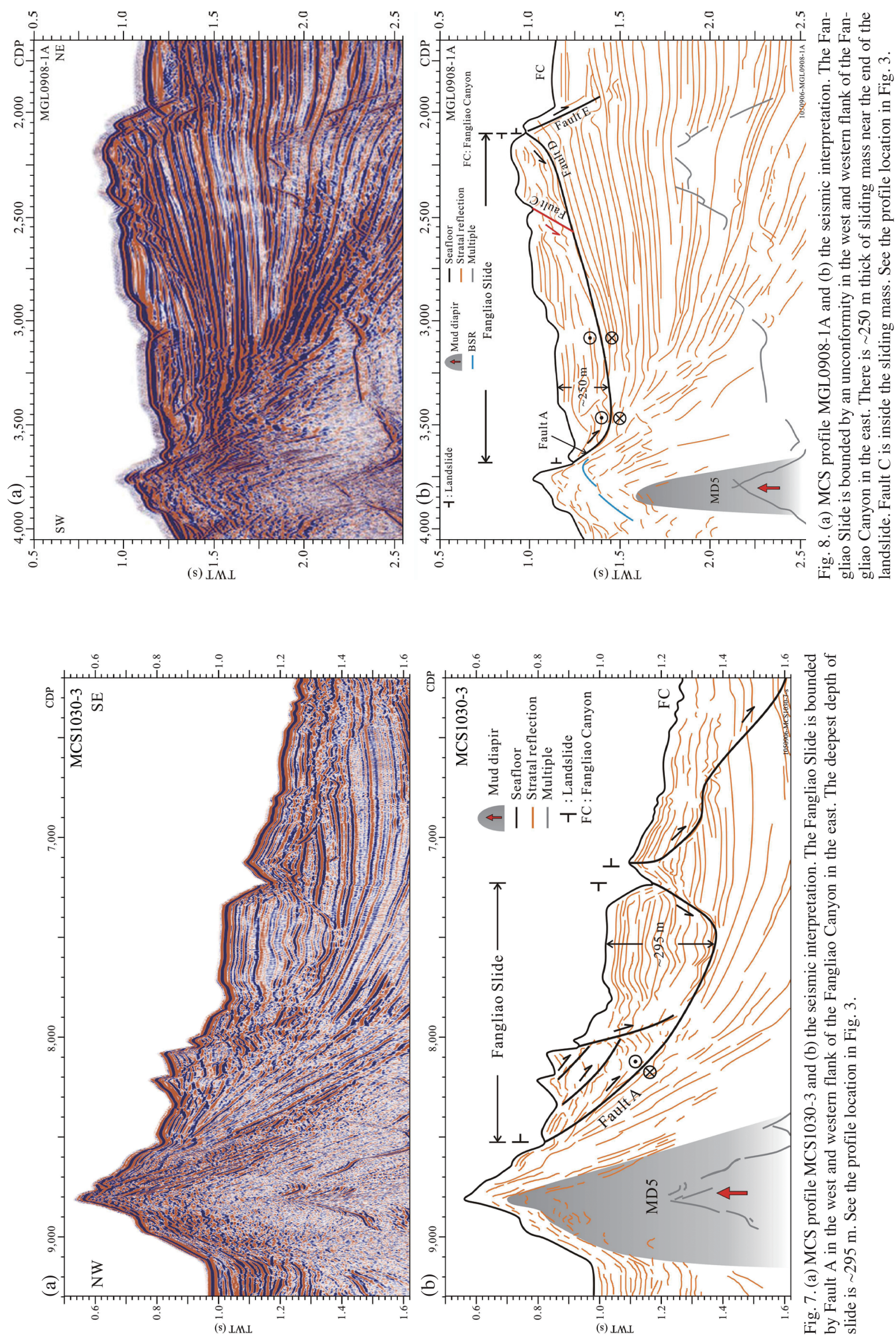

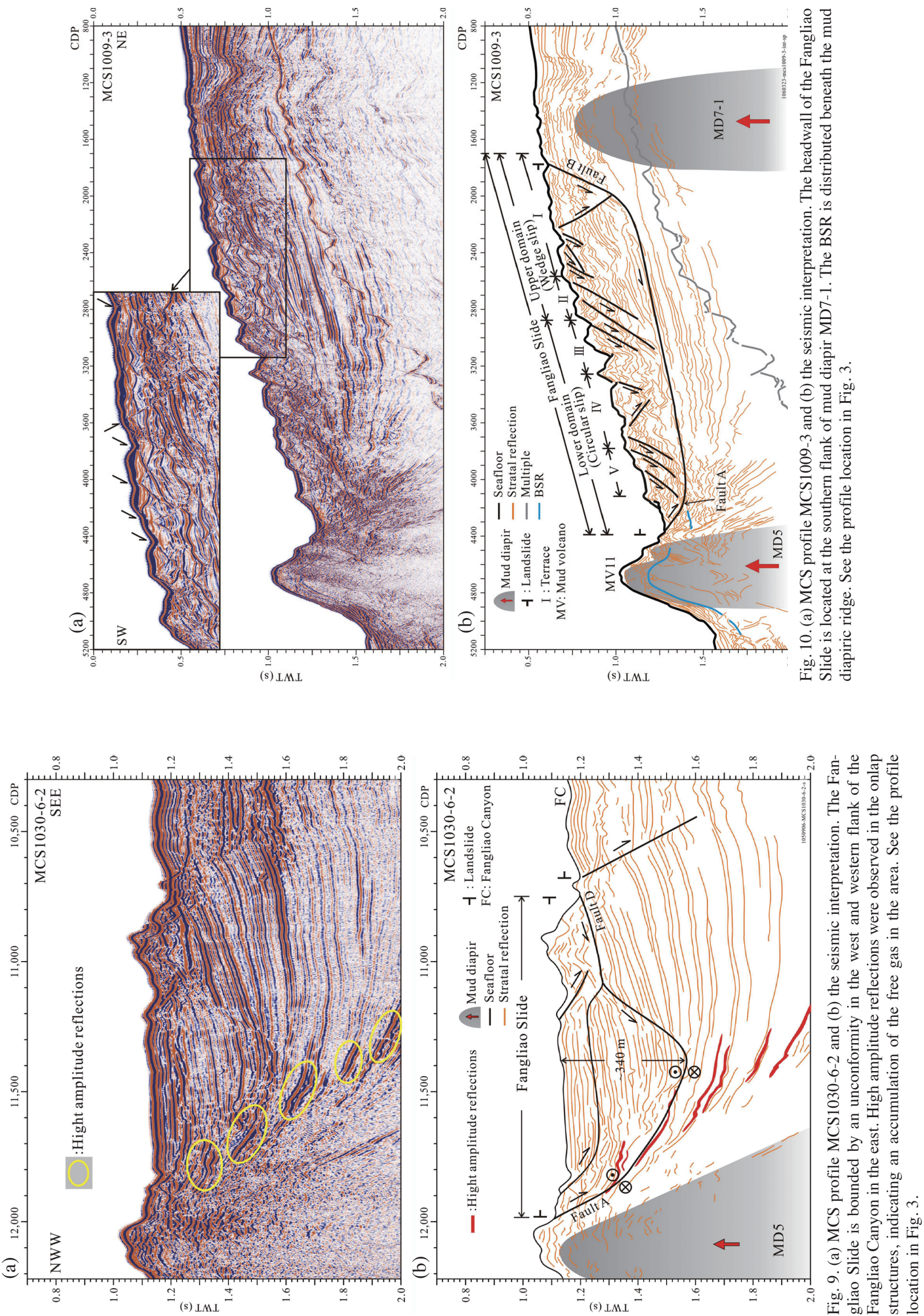
suggesting that the onlap structures have trapped free gas (Audemard and Serrano 2001; Liu et al. 2006). The gas hydrate equilibrium curve in the offshore area of SW Taiwan indicates that the water depth of $\sim 600 \mathrm{~m}$ could be a minimum pressure to enable the gas hydrate formation (Hsu et al. 2018). Because the water depth $\sim 600 \mathrm{~m}$ is also the boundary between the upper and lower domains of the Fangliao Slide (Figs. 3 - 5), the lower domain may be further affected by the gas hydrate dissociation. As mentioned previously, the seafloor morphology of the lower domain of the Fangliao Slide is different from the upper domain. Thus, the dissociated or free gas could be involved in the slumping or slope failure in the lower domain and caused a more rugged seafloor morphology and steeper slope than in the upper domain.

The continental slope off SW Taiwan can be divided into upper Kaoping slope and the lower Kaoping slope, separated by the Kaoping Canyon (Fig. 1). In the upper Kaoping slope, the gases emitting out of seabed are characterized by a mixture of thermogenic and biogenic gases (Yang et al. 2012). The high-temperature thermogenic fluids at depth can migrate upward to shallow strata through mud diapirs (Chen et al. 2014). Three sites of high heat flow up to $86-106 \mathrm{~mW} \mathrm{~m}^{-2}$ were found on tops and flanks of the mud diapirs near our study area (Shyu et al. 2006) (Fig. 1). These values are much higher than the average heat flow $\sim 64 \mathrm{~mW} \mathrm{~m}^{-2}$ off southwest Taiwan (Shyu et al. 2006), which implies that the high-temperature fluids have migrated upwards due to mud diapirism. In the lower domain, the mud diapirism of MD5 and MD6 could deliver hot fluids from depth, thus enhancing the dissociation of gas hydrate, which in turn would generate excess pore pressure, facilitating a slope failure. Because the Fangliao Slide has a very low gradient $\left(<2^{\circ}\right)$, we suggest that the slope failure was related to excess pore pressure (Kvalstad et al. 2005; Urlaub et al. 2015; Cukur et al. 2016) due to the dissociated or free gas from the base of BGHS.

However, the high overpressure in sedimentary layers can be caused not only by dissociated gas and free gas beneath BGHS but also by high sedimentation rate (Brown 1990; Hovland et al. 1997; Milkov 2000; Talukder et al. 2007). In the offshore area of SW Taiwan, high sedimentation rates from $0.7-4.5 \mathrm{~mm} \mathrm{yr}^{-1}$ were derived (Lin et al. 2014), which favors the development of mud diapirs (Sun and Liu 1993; Liu et al. 1997; Chen et al. 2014). We suppose that a high sedimentation rate has also contributed to the Fangliao Slide.

\subsection{Sliding Scenario of the Fangliao Slide}

As indicated by the BSR distribution (Fig. 1), the lower domain of the Fangliao Slide could partly cover a potential gas hydrate zone, but the upper domain of the Fangliao Slide does not. The seafloor morphologies, creeping activities and slope angles of the two domains are different. This difference indicates that the sliding mechanisms in the two domains are different. We suggest that mud diapirism and gas hydrate dissociation are two main factors for the sliding of the Fangliao Slide (Fig. 11). The mud diapirism of MD71 has probably initiated a major sliding from the headwall.

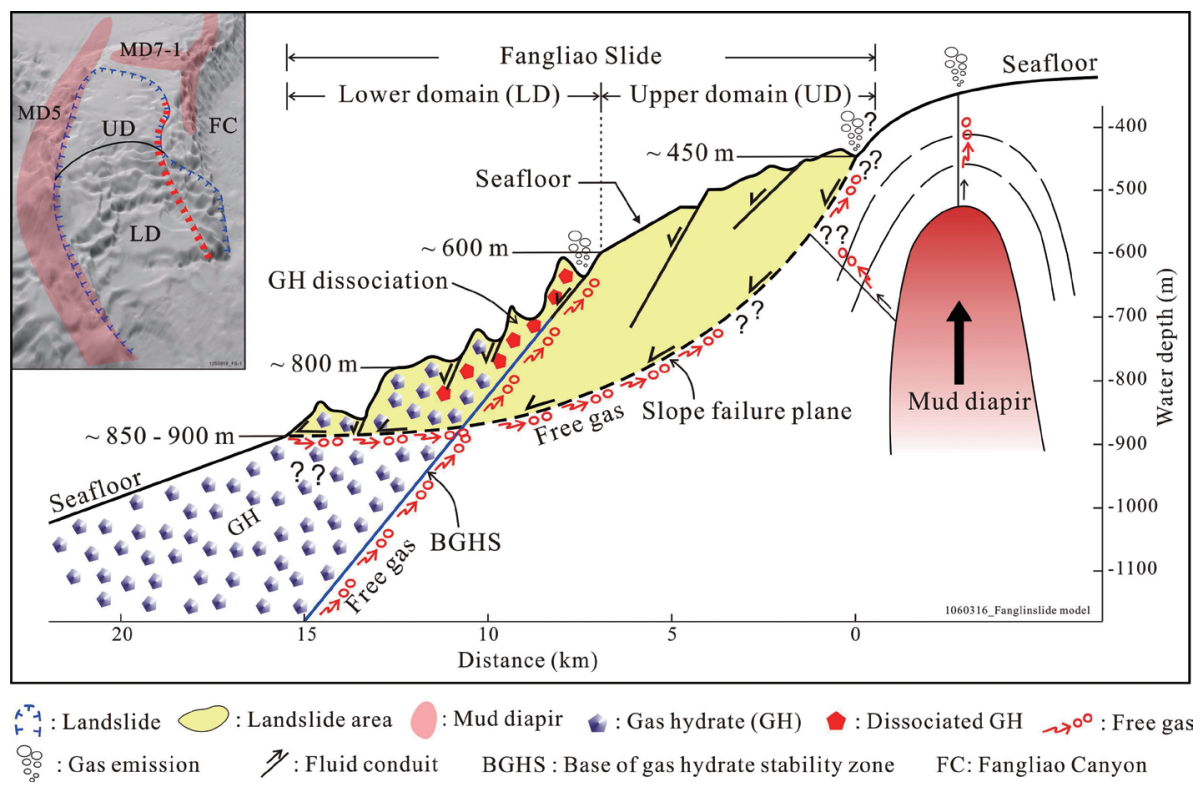

Fig. 11. A schematic model explains the sliding scenario of the Fangliao Slide. Mud diapirism and gas hydrate dissociation are two main factors for the slope failure of the Fangliao Slide. The slope failure was first triggered by mud diapirism. Free gas came out of the mud diapir could enhance the slope failure. Secondly, the gas hydrate dissociation and upward free gases could augment the slope failure in the lower domain resulting more corrugated seafloor. 
The upward migration of the free gas along the sliding surface leads to excess pore pressure may aggravate the sliding. The free gases may come from mud diapirs, dissociated gas or the free gas beneath the BGHS (Fig. 11). Because gas hydrate becomes dissociated in the shallow part of the lower domain, the upward migration of the dissociated gas and the free gas near water depth of $600 \mathrm{~m}$ could cause a second slope failure in the frontal part of the lower domain and created the corrugated seafloor morphology. Gas seeps and gas plumes are widely distributed on tops of the mud diapirs off SW Taiwan (Fig. 3) (Hsu et al. 2018). Some gas seeps and gas plumes do exist near the headwall of the Fangliao Slide and in the terrace III (Fig. 3). However, because earthquakes are quite frequent off SW Taiwan, earthquakes may also play an important role in triggering the sliding of the Fangliao Slide.

When was the initial sliding of the Fangliao Slide? Because the slope failure of the Fangliao Slide could be related to mud diapirism, the history of the mud diapirism off SW Taiwan may reveal the timing of the initial sliding. Several studies indicated that the mud diapirism was caused by the tectonic compression off SW Taiwan in Pliocene (Sun and Liu 1993; Liu et al. 1997; Chen et al. 2014). The Xiaoliuchiu islet located to the north of the Fangliao Slide is a diapiric structure and has been uplifted above the sea level (Fig. 1) (Sun and Liu 1993; Liu et al. 1997; Lacombe et al. 2004; Chen et al. 2014). The Xiaoliuchiu mudstone is the upper part of the diapiric formation in late Pliocene (Chi 1981) and major uplifting of the Xiaoliuchiu islet may occurred in Plio-Pleistocene (Lacombe et al. 2004). Therefore, we suppose that the initial sliding of the Fangliao Slide probably occurred in Plio-Pleistocene or later.

\section{CONCLUSIONS}

Based on the MCS profiles and multi-beam bathymetric data, we have identified the Fangliao Slide and five main normal faults to the west of the Fangliao Canyon. The Fangliao Slide is bounded by faults A, B, C, and D. As fault C is a continuous and pronounced structure in a high sedimentation rate setting, fault $\mathrm{C}$ and the Fangliao Slide are still active. Overall, located at water depths from $\sim 420-900 \mathrm{~m}$ the slope of the Fangliao Slide is gentle with an average angle between $\sim 1^{\circ}$ and $\sim 2^{\circ}$. The headwall has $\sim 30 \mathrm{~m}$ vertical offset and the slide has a total affected area of $\sim 116 \mathrm{~km}^{2}$ and a volume of $\sim 26 \mathrm{~km}^{3}$. The Fangliao Slide has created five bathymetric terraces and can be divided into two domains, separated at the water depth of $\sim 600 \mathrm{~m}$. The upper domain shows relatively smooth seafloor with a gentle slope of $\sim 1^{\circ}$, while the lower domain is characterized by more corrugated seafloor morphology with a steeper slope of $\sim 2^{\circ}$. Mud diapirism and gas hydrate dissociation are two main factors for slope failure of the Fangliao Slide. A mud diapirism could initiate the landslide and caused the main sliding surface.
The gas hydrate dissociation and the upward migrating free gases have probably augmented the slope failure in the lower domain, creating more corrugated bathymetry.

Acknowledgements We appreciate the crew and the technical staff of the M/V POLARIS and R/V Ocean Researcher I and II for conducting multi-beam echo sounder surveys and collecting multi-channel seismic reflection profiles. We are indebted to Dr. David Vöelker and Dr. Deniz Curkur for their valuable comments and suggestions that fruitfully improved the quality of this paper. This study was mainly supported by the Central Geological Survey, Ministry of Economic Affairs, Taiwan, under grants 101-522690400006 and 102-5226904000-05 and by the Ministry of Science and Technology, Taiwan.

\section{REFERENCES}

Audemard, F. E. and I. C. Serrano, 2001: Future Petroliferous Provinces of Venezuela. In: Downey, M. W., J. C. Threet, and W. A. Morgan (Eds.), Petroleum Provinces of the Twenty-First Century, American Association of Petroleum Geologists Memoir 74, 353-372.

Baraza, J., G. Ercilla, and C. H. Nelson, 1999: Potential geologic hazards on the eastern Gulf of Cadiz slope (SW Spain). Mar. Geol., 155, 191-215, doi: 10.1016/ s0025-3227(98)00147-9. [Link]

Berndt, C., J. Mienert, M. Vanneste, and S. Bunz, 2005: Gas hydrate dissociation and sea floor collapse in the wake of the Storegga Slide, Norway. In: Wandas, B. T. G., E. Eide, F. Gradstein, and J. P. Nystuen (Eds.), Onshore-Offshore Relationships on the North Atlantic Margin, Norwegian Petroleum Society (NPF) Special Publication, Vol. 12, 285-292, doi: 10.1016/s09288937(05)80055-4. [Link]

Bondevik, S., F. Løvholt, C. Harbitz, J. Mangerud, A. Dawson, and J. I. Svendsen, 2005: The Storegga Slide tsunami-comparing field observations with numerical simulations. Mar. Petrol. Geol., 22, 195-208, doi: 10.1016/j.marpetgeo.2004.10.003. [Link]

Booth, J. S., W. J. Winters, and W. P. Dillon, 1994: Circumstantial evidence of gas hydrate and slope failure associations on the United States Atlantic continental margin. In: Sloan, E. D., J. Happel, and M. A. Hnatow (Eds.), Natural Gas Hydrate, Annals of the New York Academy of Sciences, Vol. 715, 487-489, doi: 10.1111/j.1749-6632.1994.tb38863.x. [Link]

Brown, H. E., W. S. Holbrook, M. J. Hornbach, and J. Nealon, 2006: Slide structure and role of gas hydrate at the northern boundary of the Storegga Slide, offshore Norway. Mar. Geol., 229, 179-186, doi: 10.1016/j. margeo.2006.03.011. [Link]

Brown, K. M., 1990: The nature and hydrogeologic significance of mud diapirs and diatremes for accretionary 
systems. J. Geophys. Res., 95, 8969-8982, doi: 10.1029/ jb095ib06p08969. [Link]

Bunz, S., J. Mienert, and C. Berndt, 2003: Geological controls on the Storegga gas-hydrate system of the midNorwegian continental margin. Earth Planet. Sci.Lett., 209, 291-307, doi: 10.1016/s0012-821x(03)00097-9. [Link]

Chen, G.-Y., 1830: Taiwan Interview Catalogue, Rep. (in Chinese)

Chen, S.-C., S.-K. Hsu, C.-H. Tsai, C.-Y. Ku, Y.-C. Yeh, and Y. Wang, 2010: Gas seepage, pockmarks and mud volcanoes in the near shore of SW Taiwan. Mar. Geophys. Res., 31, 133-147, doi: 10.1007/s11001-0109097-6. [Link]

Chen, S.-C., S.-K. Hsu, Y. Wang, and C.-S. Liu, 2012: Submarine landslides in the upper Kaoping slope off SW Taiwan. 2012 The Chinese Institute of Mining \& Metallurgical Engineers Annual Convention, 2 November 2012, Kaohsiung, Taiwan, abstract, 77. (in Chinese)

Chen, S.-C., S.-K. Hsu, Y. Wang, S.-H. Chung, P.-C. Chen, C.-H. Tsai, C.-S. Liu, H.-S. Lin, and Y.-W. Lee, 2014: Distribution and characters of the mud diapirs and mud volcanoes off southwest Taiwan. J. Asian Earth Sci., 92, 201-214, doi: 10.1016/j.jseaes.2013.10.009. [Link]

Chi, W.-R., 1981: Calcareous nannoplankton from the sediments of the Liuchiuhsu, southwestern Taiwan. Proc. Geol. Soc. China, 24, 141-147.

Chiu, J.-K., W.-H. Tseng, and C.-S. Liu, 2006: Distribution of gassy sediments and mud volcanoes offshore southwestern Taiwan. Terr Atmos Ocean Sci., 17, 703-722, doi: 10.3319/TAO.2006.17.4.703(GH). [Link]

Cukur, D., S.-P. Kim, G.-S. Kong, J.-J. Bahk, S. Horozal, I.-K. Um, G.-S. Lee, T.-S. Chang, H.-J. Ha, D. Völker, and J.-K. Kim, 2016: Geophysical evidence and inferred triggering factors of submarine landslides on the western continental margin of the Ulleung Basin, East Sea. Geo-Mar. Lett., 36, 425-444, doi: 10.1007/ s00367-016-0463-5. [Link]

Dillon, W. P., W. W. Danforth, D. R. Hutchinson, R. M. Drury, M. H. Taylor, and J. S. Booth, 1998: Evidence for faulting related to dissociation of gas hydrate and release of methane off the southeastern United States. Geol. Soc. Lond. Spec. Publ., 137, 293-302, doi: 10.1144/gsl.sp.1998.137.01.23. [Link]

Doo, W.-B., S.-K. Hsu, C.-L. Lo, S.-C. Chen, C.-H. Tsai, J.-Y. Lin, Y.-P. Huang, Y.-S. Huang, S.-D. Chiu, and Y.-F. Ma, 2015: Gravity anomalies of the active mud diapirs off southwest Taiwan. Geophys. J. Int., 203, 2089-2098, doi: 10.1093/gji/ggv430. [Link]

Gardner, J. V., D. B. Prior, and M. E. Field, 1999: Humboldt Slide - a large shear-dominated retrogressive slope failure. Mar. Geol., 154, 323-338, doi: 10.1016/s00253227(98)00121-2. [Link]
Hampton, M. A., H. J. Lee, and J. Locat, 1996: Submarine landslides. Rev. Geophys., 34, 33-59, doi: 10.1029/95RG03287. [Link]

Ho, C.-S., 1986: A synthesis of the geologic evolution of Taiwan. Tectonophysics, 125, 1-16, doi: 10.1016/00401951(86)90004-1. [Link]

Hornbach, M. J., L. L. Lavier, and C. D. Ruppel, 2007: Triggering mechanism and tsunamogenic potential of the Cape Fear Slide complex, U.S. Atlantic margin. Geochem. Geophys. Geosyst., 8, Q12008, doi: 10.1029/2007GC001722. [Link]

Hornbach, M. J., S. A. Mondzie, N. R. Grindlay, C. Frohlich, and P. Mann, 2008: Did a submarine slide trigger the 1918 Puerto Rico tsunami? Science of Tsunami Hazards, 27, 22-31.

Horozal, S., J.-J. Bahk, R. Urgeles, G. Y. Kim, D. Cukur, S.-P. Kim, G. H. Lee, S. H. Lee, B.-J. Ryu, and J.-H. Kim, 2017: Mapping gas hydrate and fluid flow indicators and modeling gas hydrate stability zone (GHSZ) in the Ulleung Basin, East (Japan) Sea: Potential linkage between the occurrence of mass failures and gas hydrate dissociation. Mar. Petrol. Geol., 80, 171-191, doi: 10.1016/j.marpetgeo.2016.12.001. [Link]

Hovland, M., A. Hill, and D. Stokes, 1997: The structure and geomorphology of the Dashgil mud volcano, Azerbaijan. Geomorphology, 21, 1-15, doi: 10.1016/s0169555x(97)00034-2. [Link]

Hsu, H., 1983: Source materials on the history of natural disasters in Ching, Taiwan. Hazards Mitigation S\&T Report, Vol. 72-01, 5-6. (in Chinese)

Hsu, H.-H., C.-S. Liu, H. S. Yu, J.-H. Chang, and S.-C. Chen, 2013a: Sediment dispersal and accumulation in tectonic accommodation across the Gaoping Slope, offshore Southwestern Taiwan. J. Asian Earth Sci., 69, 26-38, doi: 10.1016/j.jseaes.2013.01.012. [Link]

Hsu, S.-K., J. Kuo, C.-L. Lo, C.-H. Tsai, W .-B. Doo, C.-Y. $\mathrm{Ku}$, and J.-C. Sibuet, 2008: Turbidity currents, submarine landslides and the 2006 Pingtung earthquake off SW Taiwan. Terr. Atmos. Ocean. Sci., 19, 767-772, doi: 10.3319/TAO.2008.19.6.767(PT). [Link]

Hsu, S.-K., S.-Y. Wang, Y.-C. Liao, T. F. Yang, S. Jan, J.-Y. Lin, and S.-C. Chen, 2013b: Tide-modulated gas emissions and tremors off SW Taiwan. Earth Planet. Sci. Lett., 369-370, 98-107, doi: 10.1016/j. eps1.2013.03.013. [Link]

Hsu, S.-K., S.-S. Lin, S.-Y. Wang, C.-H. Tsai, W.-B. Doo, S.-C. Chen, J.-Y. Lin, Y.-C. Yeh, H.-F. Wang, and C.-W. Su, 2018: Seabed gas emissions and submarine landslides off SW Taiwan. Terr. Atmos. Ocean. Sci., 29, 7-15, doi: 10.3319/TAO.2016.10.04.01. [Link]

Huh, C.-A., H.-L. Lin, S. Lin, and Y.-W. Huang, 2009: Modern accumulation rates and a budget of sediment off the Gaoping (Kaoping) River, SW Taiwan: a tidal and flood dominated depositional environment around 
a submarine canyon. J. Mar. Syst., 76, 405-416, doi: 10.1016/j.jmarsys.2007.07.009. [Link]

Korup, O., J. J. Clague, R. L. Hermanns, K. Hewitt, A. L. Strom, and J. T. Weidinger, 2007: Giant landslides, topography, and erosion. Earth Planet. Sci. Lett., 261, 578-589, doi: 10.1016/j.eps1.2007.07.025. [Link]

$\mathrm{Ku}, \mathrm{C} .-\mathrm{Y}$. and S.-K. Hsu, 2009: Crustal structure and deformation at the northern Manila Trench between Taiwan and Luzon Islands. Tectonophysics, 466, 229-240, doi: 10.1016/j.tecto.2007.11.012. [Link]

Kvalstad, T. J., L. Andresen, C. F. Forsberg, K. Berg, P. Bryn, and M. Wangen, 2005: The Storegga slide: evaluation of triggering sources and slide mechanics. Mar. Petrol. Geol., 22, 245-256, doi: 10.1016/j.marpetgeo.2004.10.019. [Link]

Kvenvolden, K. A., 1998: A primer on the geological occurrence of gas hydrate. Geol. Soc. Lond. Spec. Publ., 137, 9-30, doi: 10.1144/gsl.sp.1998.137.01.02. [Link]

Lacombe, O., J. Angelier, F. Mouthereau, H.-T. Chu, B. Deffontaines, J.-C. Lee, M. Rocher, R.-F. Chen, and L. Siame, 2004: The Liuchiu Hsu island offshore SW Taiwan: Tectonic versus diapiric anticline development and comparisons with onshore structures. C. R. Geosci., 336, 815-825, doi: 10.1016/j.crte.2004.02.007. [Link]

Leynaud, D., T. Mulder, V. Hanquiez, E. Gonthier, and A. Régert, 2017: Sediment failure types, preconditions and triggering factors in the Gulf of Cadiz. Landslides, 14, 233-248, doi: 10.1007/s10346-015-0674-2. [Link]

Li, A., R. J. Davies, and J. Yang, 2016: Gas trapped below hydrate as a primer for submarine slope failures. Mar. Geol., 380, 264-271, doi: 10.1016/j.margeo.2016.04.010. [Link]

Li, L., A. D. Switzer, Y. Wang, R. Weiss, Q. Qiu, C.-H. Chan, and P. Tapponnier, 2015: What caused the mysterious eighteenth century tsunami that struck the southwest Taiwan coast? Geophys. Res. Lett., 42, 8498-8506, doi: 10.1002/2015g1065567. [Link]

Lin, A. T., B. Yao, S.-K. Hsu, C.-S. Liu, and C.-Y. Huang, 2009: Tectonic features of the incipient arc-continent collision zone of Taiwan: Implications for seismicity. Tectonophysics, 479, 28-42, doi: 10.1016/j.tecto.2008.11.004. [Link]

Lin, C.-C., A. T. Lin, C.-S. Liu, C.-S. Horng, G.-Y. Chen, and Y. Wang, 2014: Canyon-infilling and gas hydrate occurrences in the frontal fold of the offshore accretionary wedge off southern Taiwan. Mar. Geophys. Res., 35, 21-35, doi: 10.1007/s11001-013-9203-7. [Link]

Liu, C.-S., I. L. Huang, and L. S. Teng, 1997: Structural features off southwestern Taiwan. Mar. Geol., 137, 305319, doi: 10.1016/s0025-3227(96)00093-x. [Link]

Liu, C.-S., B. Deffontaines, C.-Y. Lu, and S. Lallemand, 2004: Deformation patterns of an accretionary wedge in the transition zone from subduction to collision off- shore southwestern Taiwan. Mar. Geophys. Res., 25, 123-137, doi: 10.1007/s11001-005-0738-0. [Link]

Liu, C.-S, P. Schnürle, Y. Wang, S.-H. Chung, S.-C. Chen, and T.-H. Hsiuan, 2006: Distribution and characters of gas hydrate offshore of southwestern Taiwan. Terr. Atmos. Ocean. Sci., 17, 615-644, doi: 10.3319/ TAO.2006.17.4.615(GH). [Link]

McIver,R.D., 1982: Role of naturally occurring gas hydrates in sediment transport. AAPG Bull., 66, 789-792, doi: 10.1306/03b5a318-16d1-11d7-8645000102c1865d. [Link]

Micallef, A., D. G. Masson, C. Berndt, and D. A. V. Stow, 2009: Development and mass movement processes of the north-eastern Storegga Slide. Quat. Sci. Rev., 28, 433-448, doi: 10.1016/j.quascirev.2008.09.026. [Link]

Mienert, J., C. Berndt, J. S. Laberg, and T. O. Vorren, 2002: Slope instability of continental margins. In: Wefer, G., Billet, D., Hebbeln, D., Jørgensen, B. B., Schlüter, M. and Van Weering, T. C. E. (Eds.), Ocean Margin Systems, Springer-Verlag, Berlin Heidelberg, 179-193, doi: 10.1007/978-3-662-05127-6_11. [Link]

Mienert, J., M. Vanneste, S. Bünz, K. Andreassen, H. Haflidason, and H. P. Sejrup, 2005: Ocean warming and gas hydrate stability on the mid-Norwegian margin at the Storegga Slide. Mar. Petrol. Geol., 22, 233-244, doi: 10.1016/j.marpetgeo.2004.10.018. [Link]

Milkov, A. V., 2000: Worldwide distribution of submarine mud volcanoes and associated gas hydrates. Mar. Geol., 167,29-42, doi: 10.1016/s0025-3227(00)000220 . [Link]

Popenoe, P., E. A. Schmuck, and W. P. Dillon, 1993: The Cape Fear landslide: Slope failure associated with salt diapirism and gas hydrate decomposition. In: Schwab, W. C., H. J. Lee, and D. C. Twichell (Eds.), Submarine Landslides: Selected Studies in the U.S. Exclusive Economic Zone, U.S. Geol. Surv. Bull. 2002, 40-53.

Reed, D. L., N. Lundberg, C.-S. Liu, and B.-Y. Kuo, 1992: Structural relations along the margins of the offshore Taiwan accretionary wedge: implications for accretion and crustal kinematics. Acta Geol. Taiwan., 30, 105122.

Schmuck, E. A. and C. K. Paull, 1993: Evidence for gas accumulation associated with diapirism and gas hydrates at the head of the Cape Fear Slide. Geo-Mar. Lett., 13, 145-152, doi: 10.1007/bf01593187. [Link]

Shyu, C.-T., Y.-J. Chen, S.-T. Chiang, and C.-S. Liu, 2006: Heat flow measurements over bottom simulating reflectors, offshore southwestern Taiwan. Terr. Atmos. Ocean. Sci., 17, 845-869, doi: 10.3319/ TAO.2006.17.4.845(GH). [Link]

Sun, S.-C. and C.-S. Liu, 1993: Mud diapirs and submarine channel deposits in offshore Kaohsiung-Hengchun, southwest Taiwan. Petrol. Geol. Taiwan, 28, 1-14.

Talukder, A. R., J. Bialas, D. Klaeschen, D. Buerk, W. 
Brueckmann, T. Reston, and M. Breitzke, 2007: Highresolution, deep tow, multichannel seismic and sidescan sonar survey of the submarine mounds and associated BSR off Nicaragua pacific margin. Mar. Geol., 241, 33-43, doi: 10.1016/j.margeo.2007.03.002. [Link]

Tappin, D. R., S. T. Grilli, J. C. Harris, R. J. Geller, T. Masterlark, J. T. Kirby, F. Shi, G. Ma, K. K. S. Thingbaijam, and P. M. Mai, 2014: Did a submarine landslide contribute to the 2011 Tohoku tsunami? Mar. Geol., 357, 344-361, doi: 10.1016/j.margeo.2014.09.043. [Link]

Teng, L. S., 1990: Geotectonic evolution of late Cenozoic arc-continent collision in Taiwan. Tectonophysics, $\mathbf{1 8 3}$, 57-76, doi: 10.1016/0040-1951(90)90188-e. [Link]

Tvedt, A. B. M., A. Rotevatn, and C. A.-L. Jackson, 2016: Supra-salt normal fault growth during the rise and fall of a diapir: Perspectives from 3D seismic reflection data, Norwegian North Sea. J. Struct. Geol., 91, 1-26, doi: 10.1016/j.jsg.2016.08.001. [Link]

Twichell, D. C., J. D. Chaytor, U. S. ten Brink, and B. Buczkowski, 2009: Morphology of late Quaternary submarine landslides along the U.S. Atlantic continental margin. Mar. Geol., 264, 4-15, doi: 10.1016/j.margeo.2009.01.009. [Link]

Urlaub, M., P. J. Talling, A. Zervos, and D. Masson, 2015: What causes large submarine landslides on low gradient $\left(<2^{\circ}\right)$ continental slopes with slow $(\sim 0.15 \mathrm{~m} / \mathrm{kyr})$ sediment accumulation? J. Geophys. Res., 120, 67226739, doi: 10.1002/2015jb012347. [Link]

Wu, C.-Y., 2008: The distribution of submarine and charac- teristics landslides offshore southern Taiwan. Master Thesis, Institute of Oceanography, National Taiwan University, Taipei, Taiwan, 84 pp. (in Chinese)

Wynn, R. B., D. G. Masson, D. A. V. Stow, and P. P. E. Weaver, 2000: The Northwest African slope apron: A modern analogue for deep-water systems with complex seafloor topography. Mar. Petrol. Geol., 17, 253-265, doi: 10.1016/s0264-8172(99)00014-8. [Link]

Yang, T. F., P.-C. Chuang, C.-W. Chen, N.-C. Chen, S. Lin, Y. Wang, S.-H. Chung, and P.-C. Chen, 2012: Gas composition of cored sediments from gas hydrate potential area offshore SW Taiwan. 11th international conference on gas in marine sediments, 4-7 September 2012, Nice, France, Program and abstracts, 91.

Yeh, Y.-C., J.-Y. Lin, S.-K. Hsu, S.-C. Chen, and S.-S. Lin, 2015: Interbedded fluid activities induced slope failure in the Kaoping Slope area, southwestern offshore Taiwan. 7th International Symposium on Submarine Mass Movements and Their Consequences, 1-4 November 2015, Mac's Function Centre, Wellington, New Zealand, abstract, 94.

Yu, H.-S., C.-S. Chiang, and S.-M. Shen, 2009: Tectonically active sediment dispersal system in SW Taiwan margin with emphasis on the Gaoping (Kaoping) Submarine Canyon. J. Mar. Syst., 76, 369-382, doi: 10.1016/j. jmarsys.2007.07.010. [Link]

Yun, J. W., D. L. Orange, and M. E. Field, 1999: Subsurface gas offshore of northern California and its link to submarine geomorphology. Mar. Geol., 154, 357-368, doi: 10.1016/s0025-3227(98)00123-6. [Link] 